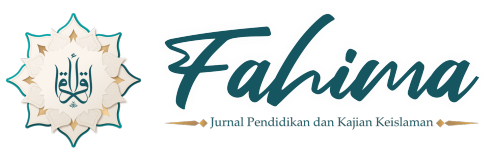

Fahima: Jurnal Pendidikan dan Kajian Keislaman

E-ISSN: 2808-4349 | P-ISSN: 2808-747X | Volume 1 No. 1 Januari 2022

\title{
PENGARUH PERILAKU GURU DAN PEMBELAJARAN DARING TERHADAP PRESTASI BELAJAR AKIDAH AKHLAQ
}

\author{
Emy Sa'adah Mahsunah" ${ }^{*}$, Maragustam Siregar ${ }^{2}$ \\ 1 SMP Negeri 2 Surakarta, Indonesia. \\ 2 UIN Sunan Kalijaga Yogyakarta
}

*Surel Penulis Koresponden: emysaadah1968@gmail.com

\begin{tabular}{|l|l|l|l|}
\hline \multicolumn{4}{|c|}{ Riwayat Artikel } \\
\hline Dikirim: 23/10/2021 & Ditinjau: 29/10/2021 & Diperbaiki: 18/11/2021 & Diterima: 28/12/2021 \\
\hline
\end{tabular}

\begin{abstract}
Abstrak
Kondisi pandemi menyebabkan proses pembelajaran dialibkan ke dalam sistem dalam jaringan atau daring. Perilaku guru mengalami perubahan dalam upaya melakukan penyesuaian seiring dengan adanya perubahan pembelajaran tersebut. Oleh karena itu penulis tertarik untuk meneliti tentang perilaku guru dan pembelajaran daring. Penelitian ini bertujuan untuk melakukan penelitian tentang pengaruh perilaku guru dan pembelajaran daring terhadap prestasi belajar Akidah Akblaq pada siswa SMP Al-Muayyad Surakarta tahun pelajaran 2020/2021.

Metode penelitian ini termasuk jenis penelitian kuantitatif dengan variable bebas (X) adalah perilaku guru dan pembelajaran daring serta variable terikat $(Y)$ prestasi belajar Akidah Akhlaq. Populasi dalam penelitian ini berjumlah 134 dan sampel $47 \%$ atau berjumlah 64 siswa.

Hasil angket dianalisis dengan uji-T dan uji-F, koefisien diterminasi (R-square) dan analisis regresi linear berganda dengan hasil selurub variable bebas $(X)$ secara simultan memiliki pengaruh positif dan signifikan terhadap variable terikat $(Y)$.
\end{abstract}

Kata Kunci: perilaku guru, pembelajaran daring, prestasi belajar Akidah Akhlaq

\begin{abstract}
The pandemic condition causes the learning process to be diverted into an online system. The teacher's behavior changes to make adjustments and the changes in learning. Therefore, the authors are interested in researching teacher behavior and online learning. This study investigates the effect of teacher behavior and online learning on Akidah Akhlaq's learning achievement in students of SMP Al-Muayyad Surakarta in the academic year 2020/2021.

This research method is a type of quantitative research with the independent variable $(X)$ being teacher behavior and online learning and the dependent variable (Y) being Akidah Akblaq learning achievement. The population in this study amounted to 134 and a sample of $47 \%$ or 64 students.
\end{abstract}


The results of the questionnaire were analyzed by T-test and F-test, termination coefficient (R-square), and multiple linear regression analysis with the results that all independent variables (X) simultaneously had a positive and significant effect on the dependent variable $(Y)$.

Keywords: teacher behavior, online learning, learning achievement in Akblaq Akblaq

\section{A. PENDAHULUAN}

Perkembangan ilmu pengetahuan dan teknologi memberikan perubahan di segala bidang, termasuk salah satunya dalam dunia pendidikan. $\mathrm{Hal}$ tersebut ditandai dengan semakin berkembang pesatnya media pembelajaran yang dipengaruhi oleh dunia teknologi dan informasi, misalnya pembelajaran berbasis computer seperti internet, serta fasilitas e-mail dan lain sebagainya, selalu berkonsentrasi pada penggunaan komputer. Kesemuanya memiliki tujuan inti yaitu mempermudah peserta didik untuk mengembangkan proses belajar. Proses belajar akan terjadi bersifat kompleks pada setiap orang disepanjang hidupnya. Proses belajar tersebut terjadi karena adanya interaksi antara seseorang dengan orang lain atau lingkungannya baik langsung ataupun tidak langsung. Sehingga belajar mengembangkan ilmu dapat terjadi kapan saja dan dimana saja.

Ilmu pendidikan dan teknologi telah berdampak pada perubahan kehidupan masyarakat. Perkembangan tersebut telah merubah paradigma manusia dalam mencari dan mendapatkan informasi yang semakin mudah. Pekerjaan yang biasanya dilakukan secara manual kini bergeser pada mesin (Sofyana \& Rozaq, 2019). Hal ini menuntut manusia untuk berfikir lebih inovatif dan maju dalam segala hal agar tidak tertinggal. Salah satu bidang yang cukup berarti dalam perkembangan ilmu pengetahuan dan teknologi adalah pendidikan. Pendidikan adalah proses komunikasi dan informasi antara pendidik pada peserta didik, media yang berperan sebagai sarana penyajian ide, gagasan dan materi pendidikan.

Pendidikan pada masa sekarang ini mengalami perubahan dalam penyampaian materi pembelajaran. Hal tersebut dikarenakan adanya pandemi Covid-19. Pandemi tersebut berdampak bagi masyarakat Indonesia, termasuk pada sektor pendidikan. Sejak diterbitkannya Surat Edaran No. 4 tahun 2020 dari Menteri Pendidikan dan Kebudayaan (Mendikbud) Nadiem Anwar Makarim, tentang pelaksanaan kebijakan pendidikan dalam masa darurat penyebaran virus corona, proses belajar dari rumah dilaksanakan dengan ketentuan sebagai berikut: (a) belajar dari rumah melalui pembelajaran daring/ jarak jauh dilaksanakan untuk memberikan pengalaman belajar yang bermakna bagi siswa, tanpa terbebani tuntutan menuntaskan seluruh capaian 
kurikulum untuk kenaikan kelas maupun kelulusan; (b) belajar dari rumah dapat difokuskan pada pendidikan kecakapan hidup antara lain mengenai pandemic Covid-19; (c) aktivitas dan tugas pembelajaran belajar dari rumah dapat bervariasi antar siswa, sesuai minat, dan kondisi masing-masing, termasuk mempertimbangkan kesenjangan akses atau fasilitas belajar di rumah; (d) bukti atau produk aktivitas belajar dari rumah diberi umpan balik yang bersifat kualitatif dan berguna dari guru tanpa diharuskan memberi skor atau nilai kuantitatif. Pendidikan adalah usaha sadar dan sistematis yang dilakukan oleh orang-orang yang disertai tanggung jawab untuk mempengaruhi peserta didik agar mempunyai sifat dan tabiat yang sesuai dengan cita-cita pendidikan (Budiono \& Suryono, 2009).

\section{B. METODE PENELITIAN}

Jenis pendekatan penelitian ini adalah studi lapangan (deskriptif kuantitatif). Penelitian deskriptif kuantitatif untuk mengetahui gambaran pengaruh prilaku guru dan pembelajaran daring terhadap prestasi belajar Akidah Akhlaq pada siswa SMP Al Muayyad Surakarta.

Metode pengambilan data menggunakan angket, wawancara dan observasi. Populasi penelitian 134 siswa dan sampel $47 \%$ sehingga ada 64 siswa.

Penelitian dilakukan di SMP Al Muayyad Surakarta tahun pelajaran 2020/2021. Penulis mengambil lokasi ini karena di SMP Al Muayyad pembelajaran yang dilakukan secara daring.

\section{HASIL DAN PEMBAHASAN}

1. Perilaku Guru

Dalam proses pendidikan perilaku guru memegang peranan penting dalam mewujudkan prestasi belajar siswa, guru yang berperilaku baik Perilaku adalah tanggapan atau reaksi individu terhadap rangsangan dan lingkungannya (Poerwadarmnita, 1995), misalnya seorang guru yang mengajar materi pelajaran kepada siswanya, seorang dokter yang melayani pasien di rumah sakit, dan seorang hakim yang memimpin jalannya persidangan. Mereka semua akan berperilaku berbeda antara satu dengan lainnya. Dengan demikian perilaku merupakan bentuk dari aktivitas yaitu aktivitas psikis, dan setiap penampilan dari kehidupan disebut sebagai aktivitas. Sebagaimana telah diketahui bahwa perilaku atau aktivitas yang ada pada individu atau organisme itu tidak timbul dengan sendirinya 
melainkan sebagai akibat dari stimulus yang diterima oleh organisme yang bersangkutan baik stimulus eksternal maupun internal. Namun sebagian besar dari perilaku organisme itu sebagai respon terhadap stimulus eksternal (Walgito, 2003).

Karakteristik perilaku guru yang disenangi oleh para siswa diantaranya adalah guru yang demokratis, suka bekerja sama, dan baik hati; guru yang sabar, adil (tidak pilih kasih), konsisten, bersikap terbuka, suka menolong, dan ramah; humoris, memiliki berbagai macam minat, menguasai bahan pelajaran; sikap menolong dan menggunakan contoh atau istilah yang baik; tidak ada yang lebih disenangi, tidak pilih kasih, dan tidak ada anak emas atau anak tiri; mempunyai pribadi yang dapat diambil contoh dari pihak anak didik dan masyarakat lingkungannya; dan tegas, sanggup menguasai kelas dan dapat membangkitkan rasa hormat pada anak; serta berusaha agar pekerjaan menarik, dapat membangkitkan keinginan- keinginan bekarja sama dengan anak didik.

\section{Pembelajaran Daring}

Pembelajaran Daring merupakan pemanfaatan jaringan internet dalam proses pembelajaran (Isman, 2016). Istilah yang digunakan adalah dalam jaringan dapat disingkat dengan daring. Penggunaan kata tersebut merupakan kata ganti dari online menjadi daring yang artinya adalah komunikasi maupun pertemuan yang dilakukan dengan menggunakan jaringan internet. Dalam proses pembelajaran program online (daring) tentunya menggunakan koneksi internet dimana jaringan yang dapat menghubungkan antara satu dengan yang lainnya. Senada dengan yang diungkapkan oleh Darmawan, pendapat lain menyatakan bahwa jaringan adalah ilmu pengetahuan komputer sistem koneksi, dan program komputer mata rantai dua komputer atau lebih (Darmawan, 2013).

\section{Prestasi Belajar}

Secara umum prestasi belajar dapat diartikan sebagai suatu hasil yang dicapai oleh seseorang setelah ia melakukan perubahan belajar, baik di sekolah maupun di luar sekolah. Namun menurut ahli pendidikan memberikan pengertian yang berbeda-beda.

Mulyono Abdurrohman menjelaskan prestasi belajar atau hasil belajar adalah kemampuan yang diperoleh anak setelah kegiatan belajar (Abdurrahman, 2003). Sedangkan Hamzah B. Uno, menyatakan hasil belajar adalah perubahan perilaku yang relatif menetap dalam diri seseorang sebagai akibat dari interaksi dengan lingkungannya (Uno, 2008). Dalam kamus besar Bahasa Indonesia disebutkan bahwa prestasi belajar adalah 
penguasaan pengetahuan atau ketrampilan yang dikembangkan oleh mata pelajaran yang lazimnya ditunjukkan dengan nilai tes atau angka yang diberikan oleh guru (Poerwadarmnita, 1995).

4. Pembahasan Hipotesis Penelitian

Berdasarkan analisis analisis Regresi Linear berganda diperoleh hasil persamaan sebagai berikut :

$\mathrm{Y}=83,006+0,053 \mathrm{X}_{1}+0,20 \mathrm{X}_{2}$

Interpretasi dari persamaan regresi linear tersebut adalah sebagai berikut :

a) $\mathrm{a}=83,006$, artinya jika perilaku guru $\left(\mathrm{X}_{1}\right)$ dan pembelajaran daring pada siswa $\left(\mathrm{X}_{2}\right)$ sama dengan nol, maka prestasi belajar $(\mathrm{Y})$ akan naik sebesar 83,006.

b) $\beta_{1}=0,053$, artinya jika adanya kenaikan variabel perilaku guru $\left(\mathrm{X}_{1}\right)$ akan meningkatkan prestasi belajar $(\mathrm{Y})$ sebesar 0,053 .

c) $\beta_{2}=0,020$, artinya jika adanya kenaikan variabel pembelajaran daring pada siswa $\left(\mathrm{X}_{2}\right)$ akan meningkatkan prestasi belajar $(\mathrm{Y})$ sebesar 0,020 .

a. Dari uji $\mathrm{F}$ diperoleh $\mathrm{F}_{\text {hitung }}=8,150>\mathrm{F}_{\text {tabel }}=2,78$ berarti ada pengaruh yang signifkan antara variabel perilaku guru $\left(\mathrm{X}_{1}\right)$ dan pembelajaran daring pada siswa $\left(\mathrm{X}_{2}\right)$ secara bersama-sama atau simultan terhadap prestasi belajar (Y) aqidah akhlak di SMP AlMuayyad Surakarta.

b. Sumbangan Efektif (SE) dan Sumbangan Relative (SR) untuk masing-masing variabel bebas terhadap regresi linearnya dapat diperoleh untuk Sumbangan Efektif (SE pembelajaran daring) sebesar 50,93\% selanjutnya Sumbangan Relative (SR perilaku) sebesar 63,65\% dan Sumbangan Relative (SR pembelajaran daring) sebesar 36,35\%.

c. Uji t digunakan untuk mengukur pengaruh variabel independen terdiri dari perilaku guru (X1) dan pembelajaran daring pada siswa (X2) terhadap variabel dependen prestasi belajar (Y) secara parsial/individu.

1) Karena $t_{\text {hitung }}=3,128>t_{\text {tabel }}=2,006$ berarti perilaku guru $\left(X_{1}\right)$ memiliki pengaruh yang signifikan terhadap prestasi belajar Aqidah Akhlak di SMP Al-Muayyad.

2) Karena $t_{\text {hitung }}=3,513>t_{\text {tabel }}=2,006$ berarti pembelajaran daring pada siswa (X2) memiliki pengaruh yang signifikan terhadap prestasi belajar Aqidah Akhlak di SMP Al-Muayyad Surakarta. 
d. Nilai $\mathrm{R}$ square diperoleh perhitungan sebesar 0,771 atau 77,1\% sedangkan $22,9 \%$ dipengaruhi oleh faktor-faktor lain yang tidak dijelaskan dalam penelitian ini sehingga dapat disimpulkan bahwa variabel independen (presepsi siswa terhadap perilaku guru dan pembelajaran daring pada siswa) berpengaruh tinggi $\left(0,771 \leq \mathrm{r}_{\mathrm{H}}\right.$ $\leq 0,91)$ terhadap variabel dependen (prestasi belajar) Aqidah Akhlak di SMP Al-Muayyad Surakarta.

Variabel pembelajaran daring pada siswa merupakan variabel dominan pada penelitian ini, karena variabel pembelajaran daring pada siswa memiliki koefisien beta $(\beta)=0,073$ lebih besar dari koefisien beta $(\beta)$ dari perilaku guru yang nilainya sebesar 0,045 . Pembelajaran daring pada siswa lebih dominan karena pembelajaran daring pada siswa sehingga variabel ini mampu meningkatkan prestasi belajar Aqidah Akhlak di SMP AL-Muayyad Surakarta.

\section{Analisa Data}

Analisis Pengarub Perilaku Guru Terhadap Prestasi Belajar Akidah Akblaq pada Siswa di SMP Al-Muayyad Surakarta Tahun Pelajaran 2020/2021

Setelah diadakan penskoran pada variabel perilaku guru didapat skor tertinggi 99 dan skor terendah 51. Setelah data tersebut dimasukkan ke dalam tabel distribusi frekuensi kemudian dibagi menjadi enam kelompok dengan panjang kelas 3 dapat dilihat seperti pada tabel 5 berikut ini :

Tabel 1. Distribusi Frekuensi Skor Perilaku Guru

\begin{tabular}{|c|c|c|c|}
\hline $\begin{array}{l}\text { Kelompok } \\
\text { skor }\end{array}$ & Interval kelas & $\begin{array}{c}\text { Frekuensi } \\
\text { absolute }\end{array}$ & Frekuensi relatif \\
\hline $\mathrm{A}$ & $<68$ & 3 & $5,6 \%$ \\
\hline $\mathrm{B}$ & $69-77$ & 22 & $40.0 \%$ \\
\hline $\mathrm{C}$ & $78-86$ & 21 & $38,2 \%$ \\
\hline $\mathrm{D}$ & $87-95$ & 7 & $12,7 \%$ \\
\hline $\mathrm{E}$ & $>96$ & 2 & $3,6 \%$ \\
\hline \multicolumn{2}{|c|}{ Total } & 55 & $100 \%$ \\
\hline
\end{tabular}

Sumber data diperoleb tabun 2021

Untuk mendapatkan gambaran yang jelas dari tabel, dapat dilihat pada histogram distribusi skor perilaku guru sebagai berikut : 


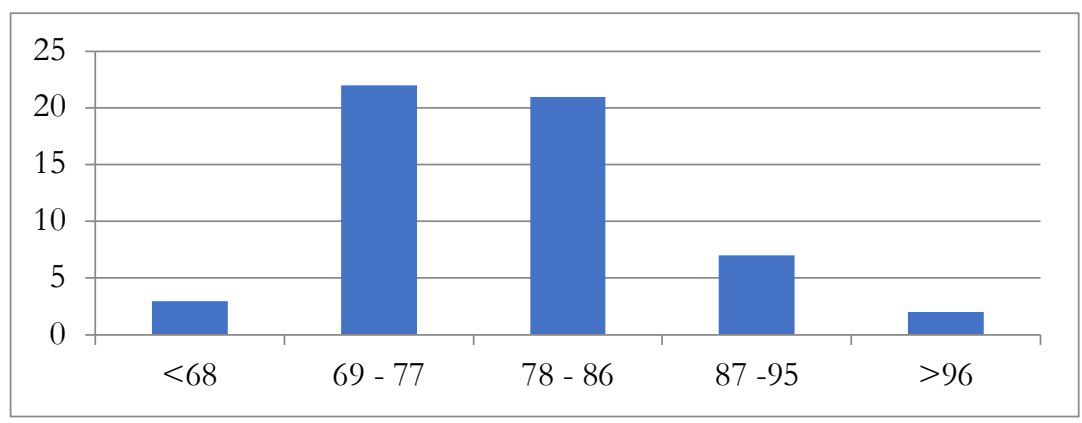

Gambar 1. Histogram frekuensi skor perilaku guru.

Dari tabel dan grafik diatas dapat dilihat bahwa variabel perilaku guru tertinggi pada frekuensi 69 - 77 dengan jumlah 22 atau 29,1 \% sedangkan frekuensi terendah pada frekuensi $51-59$ dengan jumlah 1 atau $1,8 \%$. Ini menunjukkan semakin tinggi presepsi siswa terhadap perilaku guru semakin besar pula prestasi belajar Akidah Akhlaq.

Analisis Pengaruh Pembelajaran Daring Terhadap Prestasi Belajar Akidah Akblaq pada Siswa di SMP Al-Muayyad Surakarta Tabun Pelajaran 2020/2021

Berdasarkan data penelitian dari variabel pembelajaran daring pada Bab III, data penelitian dapat dianalisis setelah diadakan penskoran pada variabel pembelajaran daring dapat dihitung skor tertinggi 85 dan skor terendah 56. Setelah data tersebut dimasukkan ke dalam tabel distribusi frekuensi, kemudian dibagi menjadi 6 kelompok dengan panjang kelas diambil 5 tampak pada tabel berikut ini :

Tabel 2. Distribusi Frekuensi Skor Pembelajaran Daring

\begin{tabular}{|c|c|c|c|}
\hline $\begin{array}{c}\text { Kelompok } \\
\text { skor }\end{array}$ & Interval kelas & $\begin{array}{c}\text { Frekuensi } \\
\text { absolute }\end{array}$ & Frekuensi relatif \\
\hline A & $<67$ & 5 & $9,1 \%$ \\
\hline B & $68-72$ & 18 & $32,7 \%$ \\
\hline C & $73-78$ & 27 & $49,1 \%$ \\
\hline D & $79-84$ & 5 & $9,1 \%$ \\
\hline E & $>85$ & 1 & $1,8 \%$ \\
\hline \multicolumn{2}{|c|}{ Total } & 55 & $100 \%$ \\
\hline
\end{tabular}

Sumber data diperoleb tabun 2021

Untuk mendapatkan gambaran yang jelas dari tabel diatas dapat dilihat pada histogram distribusi skor pemebelajaran daring sebagai berikut: 


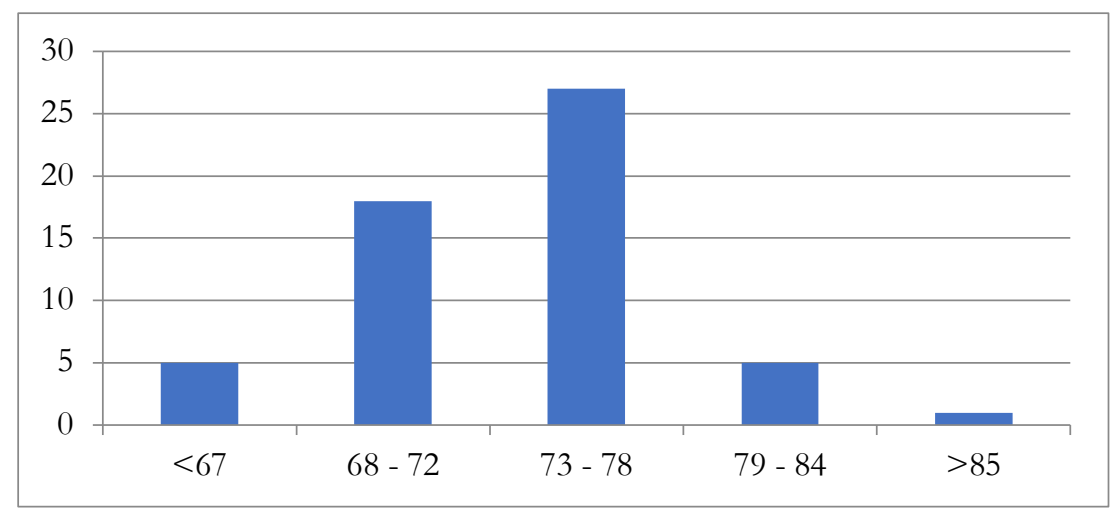

Gambar 2. Hitogram Frekuensi Skor Pembelajaaran Daring.

Dari tabel dan grafik diatas dapat dilihat bahwa variabel pembelajaran daring tertinggi pada frekuensi 73 - 78 dengan jumlah 27 atau 49,1\% sedangkan frekuensi terendah pada frekuensi $62-67$ dengan jumlah 0 atau $0 \%$.

Dari tabel dan grafik diatas dapat dilihat bahwa variabel prestasi belajaar tertinggi pada frekunsi 89 - 90 dengan jumlah 16 atau 29,1\% sedangkan frekuensi terendah pada frekuensi 85 - 89 dengan jumlah 1 atau 1,8\%.Ini menunjukkan semakin tinggi pelaksanaan pembelajaran daring semakin besar pula prestasi belajar Akidah Akhlaq

Analisis Pengaruh Perilaku Guru dan Pembelajaran Daring Terbadap Prestasi Belajar Akidah Akblaq pada Siswa di SMP Al-Muayyad Surakarta Tabun Pelajaran 2020/2021

Pengujian hipotesis keempat (pengaruh perilaku guru dan pembelajaran daring pada siswa terhadap prestasi belajar Aqidah Akhlak tahun pelajaran 2020/2021).

Model uji regresi linier berganda digunakan untuk mengetahui besarnya pengaruh koefisien variabel independen yang terdiri dari perilaku guru $\left(\mathrm{X}_{1}\right)$ dan pembelajaraj daring pada siswa $\left(\mathrm{X}_{2}\right)$ terhaadap variabel dependen prestasi belajaar Aqidah Akhlak (Y). Hasil pengolahan menggunakan program SPSS diperoleh hasil sebagai berikut: 
Tabel 3. Hasil Uji Regresi Linier Berganda

\begin{tabular}{|l|l|l|l|l|l|}
\hline \multirow{2}{*}{ No. } & \multirow{2}{*}{ variabel } & $\begin{array}{l}\text { Unstandardized } \\
\text { coefisien }\end{array}$ & $\begin{array}{l}\text { standardized } \\
\text { coefisien }\end{array}$ & t & Sig \\
\cline { 3 - 6 } & B & Beta & & 10.373 & .000 \\
\hline 2 & konstant & 83,006 & & 3.513 & .010 \\
\hline 3 & $\begin{array}{l}\text { Perilaku guru } \\
\text { daring pada siswa }\end{array}$ & 0,053 & 0,073 & 3.128 & .026 \\
\hline
\end{tabular}

\section{Sumber data diperoleh tabun 2021}

Persamaan regresi linier berganda sebagai berikut:

$\mathrm{Y}=83,006+0,053 \mathrm{X} 1+0,020 \mathrm{X} 2$ berikut :

Interprestasi dari persamaan regresi linier tersebut adalah sebagai

a. $a=83,006$, artinya jika perilaku guru $\left(\mathrm{X}_{1}\right)$ dan pemebelajaran daring pada siswa $\left(\mathrm{X}_{2}\right)$ sama dengan nol maka prestasi belajar $(\mathrm{Y})$ akan naik sebesar 83,006

b. $\beta_{1}=0,053$, artinya jika adanya kenaikan variabel perilaku guru $\left(\mathrm{X}_{1}\right)$ akan meningkatkan prestasi belajar (Y) sebesar 0,053

c. $\beta_{2}=0,20$, artinya jika adanya kenaikan variabel pembelajaran daring pada siswa $\left(\mathrm{X}_{2}\right)$ akan meningkatkan prestasi belajar $(\mathrm{Y})$ sebesar 0,026.

Semakin tinggi pelaksanaan presepsi siswa terhadap perilaku guru dan pembelajaran daring pada siswa secara bersama-sama semakin besar pula prestasi belajar Akidah Akhlaq.

\section{Ujit}

Uji t digunakan untuk mengukur pengaruh variabel independen terdiri dari perilaku guru $\left(\mathrm{X}_{1}\right)$ dan pembelajaran daring pada siswa $\left(\mathrm{X}_{2}\right)$ terhadap variabel dependen prestasi belajar $(\mathrm{Y})$ secara parsial/individu dengan membandingkan hasil thitung dengan tabel dengan taraf kesalahan alpha $=5 \%(\alpha=0,05)$. Hasil pengolahan data menggunakan SPSS diperoleh uji regresi parsial (uji t) sebagai berikut :

a. Uji pengaruh variabel perilaku guru $\left(\mathrm{X}_{1}\right)$ terhadap prestasi belajar (Y).

i. Penentuan hipotesis nihil $\left(\mathrm{h}_{\mathrm{o}}\right)$ dan hipotesis alternatif $\left(\mathrm{H}_{1}\right)$. $\mathrm{HO}=$ tidak ada pengaruh yang signifikan antara variabel perilaku guru $\left(\mathrm{X}_{1}\right)$ terhadap prestasi belajar $(\mathrm{Y})$. 
$\mathrm{H}_{1}=$ ada pengaruh yang signifikan antara variabel perilaku guru $\left(\mathrm{X}_{1}\right)$ terhadap prestasi belajar $(\mathrm{Y})$.

ii. Perhitungan $\mathrm{t}$ tabel pada level of significancy $5 \%$

$\alpha=5 \%=0,05$

$\mathrm{t}_{\text {tabel }}=(\alpha / 2, \mathrm{n}-2)$

$\mathrm{t}_{\text {tabel }}=(0,025,55-2)=(0,025,53)$

$\mathrm{t}_{\text {tabel }}=2,006$

iii. Kriteria pengujian

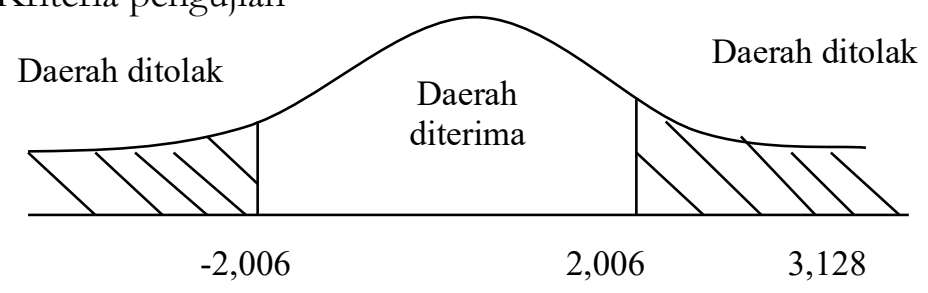

Ho diterima apabila : $\mathrm{t}_{\text {tabel }} \leq \mathrm{t}_{\text {hitung }} \leq \mathrm{t}_{\text {tabel }}$

Ho ditolak apabila : $t_{\text {hitung }}>t_{\text {tabel }}$ atau $-t_{\text {hitung }}<-t_{\text {tabel }}$

iv. Nilai thitung

Hasil analisis SPSS $t_{\text {hitung }}=3,128$ probabilitas 0,026 .

v. Kesimpulan

Karena thitung $=3,128>t_{\text {tabel }}=2,006$.

Maka, Ho ditolak dan $\mathrm{H}_{1}$ diterima berarti perilaku guru $\left(\mathrm{X}_{1}\right)$ memiliki pengaruh yang signifikan terhadap prestasi belajar Aqidah Akhlak pada siswa SMP Al-Muayyad Surakarta.

b. Uji pengaruh pembelajaran daring pada siswa $\left(\mathrm{X}_{2}\right)$ terhadap prestasi belajar (Y).

i. Penentuan hipotesis nihil (Ho) dan hipotesis alternatif $\left(\mathrm{H}_{1}\right)$

Ho = tidak ada pengaruh yang signifikan antara variabel pembelajaran daring pada siswa $\left(\mathrm{X}_{2}\right)$ terhadap prestasi belajar $(\mathrm{Y})$

$\mathrm{H}_{1}=$ ada pengaruh yang signifikan antara variabel pembelajaran daring pada siswa $\left(\mathrm{X}_{2}\right)$ terhadap prestasi belajar $(\mathrm{Y})$ 
ii. Perhitungan $t_{\text {tabel }}$ taraf level of significancy $5 \%$

$$
\begin{aligned}
& \alpha=5 \%=0,05 \\
& \mathrm{t}_{\text {tabel }}=(\alpha / 2, \mathrm{n}-2) \\
& \mathrm{t}_{\text {tabel }}=(0,025,55-2)=(0,025,53) \\
& \mathrm{t}_{\text {tabel }}=2,006
\end{aligned}
$$

iii. Kriteria pengujian

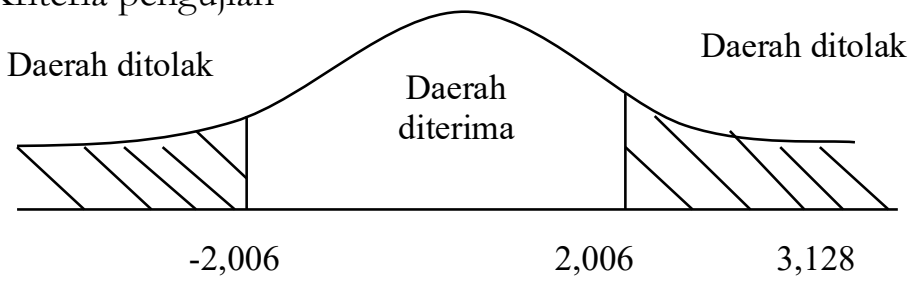

Ho diterima apabila : $t_{\text {tabel }} \leq t_{\text {hitung }} \leq t_{\text {tabel }}$

Ho ditolak apabila : $t_{\text {hitung }}>t_{\text {tabel }}$ atau $-t_{\text {hitung }}<-t_{\text {tabel }}$

iv. Nilai thitung

Hasil analisis SPSS $t_{\text {hitung }}=3,513$ probabilitas 0,010

v. Kesimpulan

Karena thitung $=3,513>\mathrm{t}_{\text {tabel }}=2,006$

Maka, Ho ditolak dan $\mathrm{H}_{1}$ diterima berarti pembelajaran daring pada siswa $\left(\mathrm{X}_{2}\right)$ memiliki pengaruh yang signifikan terhadap prestasi belajar Aqidah Akhlak pada siswa SMP Al-Muayyad Surakarta.

c. Hasil uji t

Tabel 4. Hasil Uji Regresi Parsial (Uji t)

\begin{tabular}{|c|c|c|c|c|c|}
\hline Variabel & $\mathrm{t}_{\text {thing }}$ & $\mathrm{t}_{\text {tabel }}$ & Prob. & $\alpha=5 \%$ & Ket. \\
\hline Perilaku guru & 3,128 & 2,006 & 0,026 & $<0,05$ & signifikan \\
\hline $\begin{array}{c}\text { Pembelajaran } \\
\text { daring pada } \\
\text { siswa }\end{array}$ & 3,513 & 2,006 & 0,010 & $<0,05$ & signifikan \\
\hline
\end{tabular}

Sumber olab data SPSS

\section{2. $\mathrm{Uji} F$}

Uji regresi secara simultan (uji F) dilakukan untuk mengetahui pengaruh variabel independen yang terdiri dari perilaku guru $\left(\mathrm{X}_{1}\right)$ dan 
pembelajaran daring pada siswa $\left(\mathrm{X}_{2}\right)$ terhadap prestasi belajar $(\mathrm{Y})$ secara bersama-sama, adapun langkah-langkah pengujian sebagai berikut:

a. Penentuan hipotesa nihil (Ho) dan hipotesis alternatif $\left(\mathrm{H}_{1}\right)$ Ho : $\beta_{1}=\beta_{2}=0$ : tidak ada pengaruh yang signifikan antara variabel perilaku guru $\left(\mathrm{X}_{1}\right)$ dan pembelajaran daring pada siswa $\left(\mathrm{X}_{2}\right)$ secara bersama-sama / simultan terhadap prestasi belajar (Y).

Ho : $\neq \beta_{2} \neq 0$ : ada pengaruh yang signifikan antara variabel perilaku guru $\left(\mathrm{X}_{1}\right)$ dan pembelajaran daring pada siswa $\left(\mathrm{X}_{2}\right)$ secara bersama-sama / simultan terhadap prestasi belajar $(\mathrm{Y})$.

b. Perhitungan $\mathrm{F}_{\text {tabel }}$ dengan taraf level of significancy 5\%

$$
\begin{aligned}
& \alpha=5 \%=0,05 \\
& F_{\text {tabel }}=(\alpha: \mathrm{k}, \mathrm{n}-1-\mathrm{k}) \\
& \mathrm{F}_{\text {tabel }}=(0,05: 3:(55-1-2) \\
& \mathrm{F}_{\text {tabel }}=2,78
\end{aligned}
$$

c. Kriteria pengujian

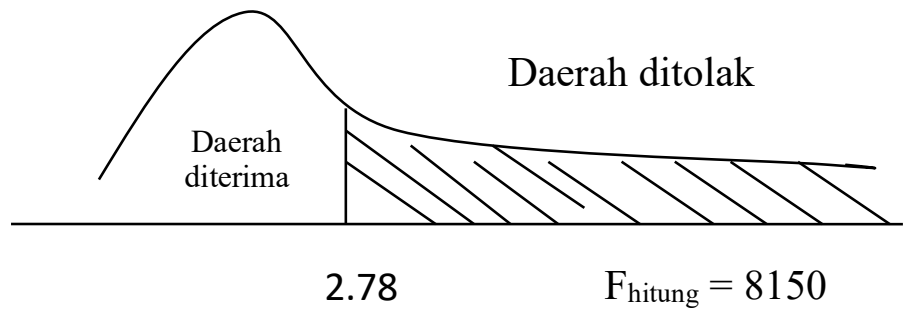

Ho diterima apabila $\mathrm{F}_{\text {hitung }} \leq \mathrm{F}_{\text {tabel }}$

Ho ditolak apabila $\mathrm{F}_{\text {hitung }} \geq \mathrm{F}_{\text {tabel }}$

d. Nilai $F_{\text {hitung }}$

Hasil analisis SPSS $F_{\text {hitung }}=8,150$ probabilitas 0,039

e. Kesimpulan

Karena $\mathrm{F}_{\text {hitung }}=8,150 \geq \mathrm{F}_{\text {tabel }}=2,78$

Maka Ho ditolak dan menolak $\mathrm{H}_{1}$, berarti ada pengaruh yang signifikan antara variabel perilaku guru $\left(\mathrm{X}_{1}\right)$ dan pembelajaran daring pada siswa $\left(\mathrm{X}_{2}\right)$ secara bersama-sama atau simultan terhadap prestasi belajar (Y) Aqidah Akhlak pada siswa SMP AlMuayyad Surakarta. 


\section{Sumbangan Efektif}

Sumbangan efektif dapat dirumuskan sebagai berikut :

$$
\mathrm{SE}=\frac{\text { bxcrossproduct } x 2}{\text { Regresion }}
$$

Dari rumus ini kemudian dimaksukkan nilai-nilai dari hasil nilai uji SPSS sebelumnya seperti yang terlihat dalam tabel berikut.

Tabel 5. Nilai Sumbangan Efektif

\begin{tabular}{|l|c|c|c|c|}
\hline \multicolumn{1}{|c|}{ Variabel } & $\mathrm{b}$ & $\begin{array}{c}\text { Cross } \\
\text { product }\end{array}$ & Regresi & $\begin{array}{c}\text { Total } \\
\text { SE }\end{array}$ \\
\cline { 1 - 3 } Perilaku guru & 0,20 & 12,164 & \multirow{2}{*}{4,071} & $77,1 \%$ \\
\cline { 1 - 3 } $\begin{array}{l}\text { Pembelajaran } \\
\text { daring }\end{array}$ & 0,53 & 6,253 & & \\
\hline
\end{tabular}

Sumber olab data SPSS

SE perilaku guru $=\frac{0,20 \times 12,164 \times 0,771}{4,071}=0,4907=49,07 \%$

SE pembelajaran daring $=\frac{0,53 \times 6,253 \times 0,771}{4,071}=0,5093=50,93 \%$

Berdasarkan hasil di atas dapat dihitung Sumbangan Relative sebagai berikut:

SR perilaku guru $=\frac{0,4907}{0,771}=0,6365=63,65 \%$

SR pembelajaran daring $=\frac{0,5093}{0,771}=0,3635=36,35 \%$

4. Uji Kesesuaian Model (Uji Determinasi/ $\mathbf{R}^{2}$ )

Berdasarkan nilai $\mathrm{R}$ square diperoleh perhitungan sebesar 0,771 atau $77,1 \%$ artinya variabel-variabel independen yang terdiri dari perilaku guru $\left(\mathrm{X}_{1}\right)$ dan pembelajaran daring pada siswa $\left(\mathrm{X}_{2}\right)$ dapat menjelaskan prestasi belajar (Y) sebesar $61,6 \%$ dan sisanya sebesar $22,9 \%$ dipengaruhi oleh variabel lain yang tidak digunakan dalam penelitian ini, misalnya minat belajar, semangat belajar, motivasi, lingkungan belajar, dan lain-lain.

Dari hasil tersebut dapat disimpulkan bahwa variabel independen (perilaku guru dan pembelajaran daring pada siswa) berpengaruh tinggi $\left(0,71 \leq \mathrm{r}_{\mathrm{H}} \leq 0,91\right)$ terhadap variabel dependen (prestasi belajar)

5. Variabel Dominan 
Koefisien beta $(\beta)$ digunakan untuk mengetahui variabel yang dominan diantara ketiga variabel bebas, hasil analisis regresi linear berganda diperoleh koefisien beta masing-masing variabel sebagai berikut :

Tabel 6. Variabel dominan

\begin{tabular}{|l|c|}
\hline Variabel & Koefisien beta \\
\hline Perilaku guru $\left(\mathrm{X}_{1}\right)$ & 0,045 \\
Pembelajaran daring pada siswa $\left(\mathrm{X}_{2}\right)$ & 0,073 \\
\hline
\end{tabular}

Sumber data diolah

Koefisien beta tertinggi adalah pembelajaran daring pada siswa $\left(\mathrm{X}_{2}\right)$ sebesar 0,073 sehingga dapat diinterpretasikan dalam penelitian ini pengaruh yang paling dominan adalah pembelajaran daring pada siswa dibandingkan dengan variabel perilaku guru.

\section{KESIMPULAN}

Pelaksanaan pembelajaran daring di SMP Al-Muayyad Surakarta berjalan dengan baik sesuai dengan standar pendidikan yang diberlakukan. Guru dalam mengajar pembelajaran daring selalu mempersiapkan perangkat pembelajaran seperti RPP, Silabus, Instrumen penilaian dan lain sebagainya. Guru dalam mengajar daring juga memanfaatkan beberapa media yang ada, jadi pembelajaran tidak berkesan monoton pada penugasan saja. System pembelajaran daring yang ditetapkan dari sekolah juga melalui pertimbangan dengan orang tua siswa. Guru selalu memberikan materi pembelajaran berupa video pembelajaran, whatsapp, google form, sehingga siswa akan tetap belajar meskipun di rumah. Dan orang tua siswa sebagian besar antusias dan berusaha untuk mengusahakan agar tetap dapat mendampingi putra-putrinya dalam belajar di rumah.

Penelitian ini membahas masalah pengaruh perilaku guru dan pembelajaran daring pada siswa terhadap prestasi belajar Aqidah Akhlak di SMP Al-Muayyad Surakarta. Berdasarkan hasil analisis data, dapat ditarik kesimpulan sebagai berikut :

1. Pengaruh Perilaku guru terhadap prestasi belajar Aqidah Akhlak mengindikasikan bahwa siswa memiliki kategori yang baik pada interval (69-77). Hasil penskoran dari kuesioner pada variabel perilaku guru dapat dihitung skor tertinggi 99 dan skor terendah 51, setelah data tersebut dimasukkan ke dalam tabel distribusi frekuensi kemudian dibagi menjadi 6 kelompok dengan panjang kelas 3 tampak pada tabel, mengindikasikan 
bahwa siswa memiliki prestasi belajar yang sedang karena jumlah frekuensi tertinggi pada frekuensi (69-77) dengan jumlah 22 atau (29,1\%).

2. Pengaruh pembelajaran daring terhadap prestasi belajar Aqidah Akhlak mengindikasikan bahwa siswa memiliki kategori yang sedang pada interval (73-78). Hasil penskoran dari kuisioner pada variabel pembelajaran daring dapat dihitung skor tertinggi 85 dan skor terendah 56. Setelah data tersebut dimasukkan ke dalam tabel distribusi frekuensi, kemudian dibagi menjadi 6 kelompok dengan dan panjang kelas diambil 5, mengindikasikan bahwa siswa memiliki prestasi belajar yang sedang karena jumlah frekuensi tertinggi pada frekuensi (73-78) dengan jumlah 27 atau (49,1\%).

3. Pengaruh perilaku guru dan pembelajaran daring terhadap prestasi belajar Akidah Akhlaq pada siswa kelas VIII SMP Al-Muayyad Surakartatahun pelajaran 2020/2021 sebagai berikut: Pengaruh positif antara perilaku guru terhadap prestasi belajar Aqidah Akhlak siswa SMP Al-Muayyad Surakarta, maka $\mathrm{H}_{\circ}$ pada penelitian ini terbukti. Pengaruh positif antara pembelajaran daring terhadap prestasi belajar Akidah Akhlaq SMP AlMuayyad Surakarta, maka $\mathrm{H}_{\mathrm{o}}$ pada penelitian ini terbukti.Variable independen (perilaku guru dan pembelajaran daring pada siswa) berpengaruh tinggi $\left(0,71 \leq \mathrm{r}_{\mathrm{H}} \leq 0,91\right)$ terhadap variable dependen (prestasi belajar) dengan nilai $\mathrm{R}_{\text {square }}=0,771$ atau $77,1 \%$.Sumbangan Efektif (SE) dan Sumbangan Relative (SR) untuk masing-masing untuk variable bebas terhadap regresi linearnya dapat diperoleh untuk Sumbangan Efektif (SE perilaku guru) sebesar 49,04\% dan Sumbangan Efektif (SE pembelajaran daring) sebesar 50,93\%, selanjutnya Sumbangan Relative (SR perilaku guru) sebesar 63,65\% dan Sumbangan Relative (SR Pembelajaran Daring) sebesar $36,35 \%$. 


\section{E. REFERENSI}

Abdurrahman, M. (2003). Pendidikan bagi anak berkesulitan belajar. Rineka Cipta.

Budiono, A. M., \& Suryono, S. (2009). Pengantar Ilmu Pendidikan. Universitas Negeri Semarang. https:/ / opac.perpusnas.go.id/DetailOpac.aspx?id $=613590$

Darmawan, D. (2013). Pendidikan teknologi informasi dan komunikasi teori dan aplikasi / Deni Darmawan. Remaja Rosdakarya.

Isman, M. (2016). Pembelajaran Moda Dalam Jaringan (Moda Daring). http://publikasiilmiah.ums.ac.id/handle/11617/7868

Poerwadarmnita. (1995). Kamus Besar Bahasa Indonesia. Balai Pustaka.

Sofyana, L., \& Rozaq, A. (2019). Pembelajaran Daring Kombinasi berbasis WhatsApp pada Kelas Karyawan Prodi Teknik Informatika Universitas PGRI Madiun. Jurnal Nasional Pendidikan Teknik Informatika: JANAPATI, 8(1), 81-86. https://doi.org/10.23887/janapati.v8i1.17204

Uno, H. B. (2008). Model Pembelajaran Proses Belajar Mengajar yang Kreatif Dan Efektif. Budi Aksara.

Walgito, B. (2003). Psikologi Sosial: Suatu Pengantar. Andi Offset. 